\title{
生态水利工程设计问题分析
}

\author{
李宝锋 \\ 长春市水土保持工作站 \\ DOI:10.32629/btr.v2i11.2629
}

[ 摘 要] 在经济可持续发展中,水利工程的作用不容小䖋。目前阶段,水利工程项目的发展速度加快,但同样也引发了一系列环境问题。为此,尽 量规避水利工程破坏生态环境已经成为亟待解决的问题。其中,生态水利工程隶属水利工程分支,基于可持续发展战略形式,为全新水利工程模 式。基于此,文章将生态水利工程作为主要研究内容,重点阐述其中的设计问题,希望有所帮助。

[关键词] 生态水利工程; 设计问题; 分析

在经济发达的社会环境中, 环境污染与资源紧缺的问题逐渐凸显出 来。要想对这一问题加以解决, 要求各方社会力量的配合, 践行可持续发展 理念, 在节能与环保等多个角度切入, 使环境与资源压力得以缓解。在生态 水利工程设计中, 要正确认知生态保护的重要作用, 充分利用科学化思想, 尊重生态自然规律, 促进生态水利工程的可持续发展。由此可见, 深入研究 并分析生态水利工程设计问题十分有必要。

\section{1 生态水利工程设计问题闸释}

1.1设计标准缺失

根据国内生态水利工程落实现状了解到, 国内尚未具备详细的生态水 利工程设计标准, 加之工程发展时间不长, 标准的规范性与统一性缺失, 对 整体设计效果产生了不利影响。另外, 由于我国地域广阔, 不同区域地理特 征差异明显, 很难运用统一化标准规范水利工程设计方案, 而且大多数设 计工作人员抱有侥幸, 并没有结合地质状况与水文特点实施调查, 导致人 力物力资源浪费严重, 甚至会破坏生态环境, 对居民生命健康造成了严重 威胁。

1.2 设计专业人才缺失

生态水利工程设计对设计工作人员提出了较高要求, 对相关知识进行 学习, 并对有关生态环境保护的知识加以掌握。但是, 根据生态水利工程人 员状况, 人才相对匮乏。现阶段, 生态水利工程属于全新学科, 所以高等院 校的课程开设尚未普及, 且师资力量薄弱, 直接影响了人才的质量与数量, 难以保证生态水利工程设计质量满足需求。

1.3 设计人员生态环境认识水平不高

在实践过程中, 生态环境技术工作人员与设计、建设工作人员交流不 多, 使设计工作人员的生态环境认识度不高, 无法正确认知生态理念的重 要性。与此同时, 在传统的水利工程设计模式影响之下, 很多设计工作人员 的生态环境认知能力不足, 实践经验缺失, 使得设计中缺少生态理念, 无法 将工程项目的价值充分发挥出来。

\section{2 优化生态水利工程设计的有效路径}

2. 1 参考工程实际情况设计标准要求

受地域性因素影响, 各地区资源特点的差异也十分明显, 所以在设计 生态水利工程中, 要综合考虑水资源的具体特点, 对区域间差异加以综合 考虑, 进一步提高工程项目的科学合理水平。

地方政府部门要对当地地理特征与水文特点相互结合, 进而制定相对 应的技术流程规范要求, 在编制技术流程与实施规范的基础上, 不断强化 设计流程合理程度。与此同时, 对国外现代化水利建设经验加以引进, 特别 是素质水平较高的人才, 进一步完善既有生态水利工程项目的标准, 深入
研究工程项目的设计规范等内容。

2. 2全面培养工程设计专业人才

第一, 生态水利工程企业要全面培养设计人才, 定期组织并举办培训 课程并实施考核, 使设计人才具备更强的自主学习意识与能力。也可借助 外出学习形式, 对生态水利工程的设计知识进行学习, 在实践操作中灵活 应用。

第二, 不断鼓励高等院校开设生态水利工程的相关课程, 保证学生对 基本的生态学常识基础加以了解, 并对生态工程经验进行积累, 使生态水 利工程企业获得充足的人力资源。

第三, 组建生态水利工程设计队伍, 在成员互相交流与沟通的基础上, 对设计经验进行分享与总结, 以保证设计工作质量的不断提高。

2.3 优化设计人员的生态环境认知水平

即便在生态水利工程中, 生态环境意识占据基础地位, 但根据实践调 查结果显示, 大部分生态水利工程的工作人员, 其生态意识的认知程度并 不高。在这种情况下, 必须使其认知程度提高, 形成生态思想, 才能够增强 工程项目的设计合理性。为此, 生态水利工程企业要针对工作人员实施综 合性培训, 对环境污染现状形成深入了解, 并主动思考环境问题, 在工程设 计标准中融入环境理念。在实践过程中, 严格审核水利工程, 以保证与环保 设计要求相契合, 在增强设计工作人员生态意识的同时, 优化其综合设计 的能力, 为水利工程项目设计工作的顺利进行奠定坚实基础。

\section{3 结束语}

综上所述, 国民经济的发展与生态水利工程建设存在紧密关联, 而设 计工作在工程建设中占据重要地位。在水利工程施工建设期间, 不应过于 强调经济效益, 同样要关注社会影响与环境保护的重要性。只有综合考虑 经济和社会效益, 才能够促进水利工程项目的全面可持续发展。

[参考文献]

[1]汪禽汤, 炜华.生态水利工程设计存在的问题及措施探讨 [J].建筑 工程技术与设计,2019,(23):2987.

[2]马欣欣.生态水利工程设计存在的问题及措施探讨 [J].建筑工程技 术与设计,2019,(22):2397.

[3]徐建华, 李兴龙. 生态水利工程设计存在的问题及措施探讨 [ J]. 工程 技术研究,2019,4(14):241-242.

[4]周王斌.探讨水利工程规划中生态环境设计的若千问题[J].建筑工 程技术与设计,2019,(14):398.

[5]崔寿贵. 探讨水利工程规划中生态环境设计的若千问题[J]. 山东工 业技术,2019,(7):121。 